\title{
Role of interleukin-17 in chondrocytes of herniated intervertebral lumbar discs
}

\author{
PENG TIAN $^{1 *}$, ZHI-JUN LI $^{2 *}$, XIN FU $^{1}$ and XIN-LONG MA ${ }^{1,2}$ \\ ${ }^{1}$ Department of Orthopedics, Tianjin Hospital, Tianjin 300211; ${ }^{2}$ Department of Orthopedics, \\ General Hospital of Tianjin Medical University, Tianjin 300052, P.R. China
}

Received July 15, 2014; Accepted March 20, 2015

DOI: $10.3892 /$ etm.2015.2449

\begin{abstract}
Lumbar disc herniation (LDH) is a common cause of lumbosacral radiculopathy. An autoimmune response to a herniated nucleus pulposus (NP) has been suggested to play an important role in the initiation of radiculopathy. Interleukin-17 (IL-17) is a cytokine associated with inflammation and autoimmunity. The presence of IL-17 has been studied in patients with $\mathrm{LDH}$; however, extensive investigation into the expression of IL-17 in different disc pathologies of LDH has not yet been conducted. The aim of the present study was to investigate the role of neovascularization and hypertrophic chondrocytes in herniated intervertebral lumbar discs. Fifty-two intervertebral lumbar disc specimens were extracted from 46 patients with LDH and were subsequently classified as either contained or non-contained disc herniation ( $\mathrm{CDH}$ and $\mathrm{NCDH}$, respectively). The specimens were stained with hematoxylin and eosin or toluidine blue, or were immunostained with polyclonal antibodies to IL-17 using the streptavidin-peroxidase method. The neovascular tissue and staining results were graded to establish the histological differences between the two herniation types. The intervertebral discs (IVDs) obtained from patients with NCDH showed significantly more neovascularization and granulation tissue than the discs obtained from patients with $\mathrm{CDH}(\mathrm{P}<0.05)$. Furthermore, hypertrophic chondrocytes were more abundant in the NCDH specimens than in the $\mathrm{CDH}$ specimens $(\mathrm{P}<0.05)$. Similarly, the number of IL-17-immunoreactive cells was significantly higher in the
\end{abstract}

Correspondence to: Dr Peng Tian, Department of Orthopedics, Tianjin Hospital, 406 Jiefangnan Road, Tianjin 300211, P.R. China E-mail: tianpeng007@foxmail.com

Dr Xin-Long Ma, Department of Orthopedics, General Hospital of Tianjin Medical University, 154 Anshan Street, Tianjin 300052, P.R. China

E-mail: xinl_ma2010@163.com

${ }^{*}$ Contributed equally

Key words: intervertebral disc, chondrocyte, interleukin-17, lumbar region
$\mathrm{NCDH}$ specimens than that in the $\mathrm{CDH}$ specimens $(\mathrm{P}<0.01)$. In conclusion, local inflammation and autoreactive immune activation may play an important role in the pathogenesis of $\mathrm{LDH}$. These results also suggest a role of chondrocytes in the repair of herniated IVDs.

\section{Introduction}

Lumbosacral radiculopathy is a relatively common clinical condition that occurs as a result of mechanical deformation and biochemical irritation caused by intervertebral disc (IVD) herniation. Although mechanical nerve root compression may contribute to the symptoms of radiculopathy, it is currently believed that an inflammatory or immune component is the key mediator of radicular pain $(1,2)$. The nucleus pulposus (NP) tissue may be autoantigenic; this theory is supported by the accumulation of lymphocytes in regional lymph nodes following exposure to autologous NP (3) and injury to the annulus fibrosus (4). A number of animal studies applied healthy autologous NP to spinal nerve roots, as a model of non-compressive disc herniation, which induced an inflammatory and immune response resulting in neuronoglial apoptosis, a decrease in nerve conduction velocity, the onset of gait abnormality, mechanical allodynia and thermal hyperalgesia (5-12). Inflammatory cells (predominantly macrophages) in herniated disc tissue that have been harvested during surgery synthesize proinflammatory mediators and cytokines, such as phospholipase A2 $(13,14)$, leukotrienes (14), immunoglobulins (14), fibroblast growth factor (15-17), matrix metalloproteinases (18-21), nitric oxide (18-20), interleukin (IL)-1 (14,22-24), IL-4 (25), IL-6 (14,19,22,23,26,27), IL-8 (27), IL-10 (26), IL-17 (12), IL-20 (28), IL-23 (12), prostaglandin E2 (18,19,22,27,29), tumor necrosis factor- $\alpha(14,22-24,30-32)$, interferon $\gamma$ (25), granulocyte-macrophage colony stimulating factor $(22,26)$, nerve growth factor (21), substance P $(21,33)$, cyclooxygenase-2 $(31,32,34,35)$, monocyte chemoattractant protein-1 (36) and vascular endothelial growth factor (37).

Numerous studies have focused on a new subset of T cells, known as T-helper type 17 (Th17) cells, which are associated with autoimmune diseases. IL-17 is a cytokine associated with inflammation, autoimmunity (38), inflammatory bowel disease (39), psoriasis (40), rheumatoid arthritis (41) and the defense against certain bacterial and viral infections (42). IL-17A and IL-17B, along with the IL-17 receptor and IL-17 
receptor-like protein, have been found to localize in chondrocytes in the fracture callus and in the epiphyseal growth plate during an endochondral differentiation program (43).

Previous studies have examined the association between IL-17 and disc diseases, particularly lumbar disc herniation (LDH). According to the findings of those studies, IL-17 participates in the local inflammatory response in an autologous NP model of radiculopathy (44). The presence of IL-17 has been examined in herniated disc tissues of patients with $\mathrm{LDH}$, demonstrating the involvement of Th17 lymphocytes in disc degeneration $(45,46)$. IL-17 is currently being used as a marker of inflammation and immune activation. There is, however, limited research on the expression of IL-17 in different disc pathologies in LDH. The present study investigated the differences in IL-17 expression among patients with different types of LDH. Specimens were collected from patients who had undergone surgery and were investigated through pathological and immunological observations.

\section{Materials and methods}

Patients. IVD specimens from 46 patients who had received conservative therapy for $\geq 3$ months between March and October 2009 were obtained through primary lumbar discectomy for radiculalgia. The subjects comprised 24 men and 22 women aged 18-76 years (mean age, 45.2 \pm 13.1 years) (Table I). Patients showed either no improvement in radiculopathy or initial improvement during conservative therapy, which was, however, followed by relapse. Patients were assessed according to symptoms, physical examination (sensation, muscle strength and straight leg raising test) and image data. Certain patients also underwent the femoral nerve stretch test if it was considered that the L3/4 herniated lumbar disc could affect the femoral nerve. The study protocol was approved by the Ethics Committee of Tianjin Hospital (Tianjin, China). Herniation was present at L3/4 in 3 discs, $\mathrm{L} 4 / 5$ in 32 discs and L5/S1 in 17 discs. The presence or absence of perforation of the posterior longitudinal ligament could not be conclusively confirmed by magnetic resonance imaging. The type of herniation was, therefore, confirmed during the surgery, based on whether or not the annulus fibrosus was broken. The patients were divided into two groups: The contained disc herniation $(\mathrm{CDH})$ and the non-contained disc herniation $(\mathrm{NCDH})$ groups. Specimens collected during surgery were examined by immunopathology.

Preparation of pathological specimens. IVDs were harvested during discectomy and specimens underwent light microscopic examination. The specimens for light microscopy were fixed in $10 \%$ formalin and embedded in paraffin. Paraffin sections (5- $\mu \mathrm{m}$-thick) were cut and stained with hematoxylin and eosin and toluidine blue. Surgical specimens were qualitatively graded according to whether or not inflammatory changes existed in the herniation (47) (Fig. 1) and hypertrophic chondrocytes were present in the specimens (Fig. 2), as shown by the amount of toluidine blue staining.

Immunohistochemistry of IL-17. Immunohistochemistry of IL-17 was performed according to the streptavidin-peroxidase (SP) method, using an SP-9001 Rabbit SP kit (Tianjin Haoyang Biological Manufacture Co., Ltd., Tianjin, China).
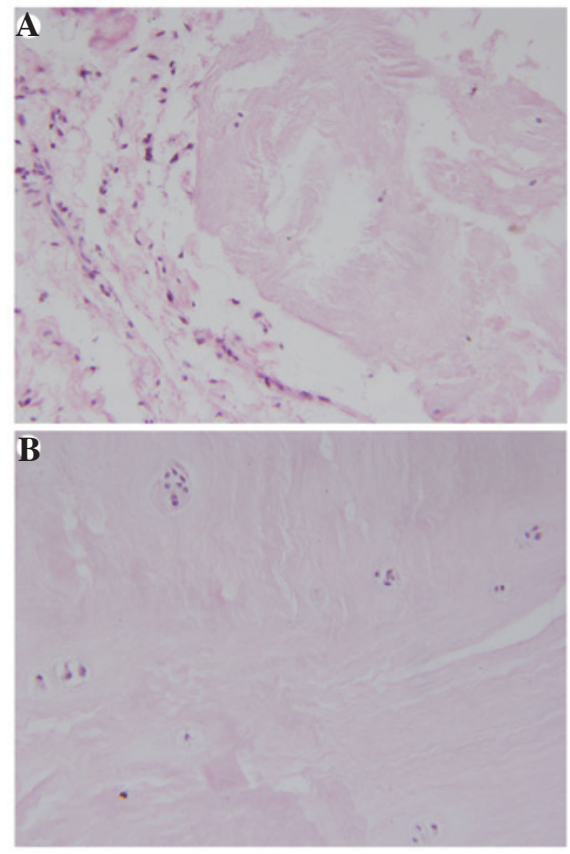

Figure 1. Classification of surgical specimens based on pathological findings. (A) Grade 1, inflammatory cell infiltration and neovascularization in the herniated tissue (H\&E staining; original magnification, $x 200$ ). (B) Grade 2, no inflammatory cell infiltration or neovascularization in the herniated tissue (H\&E staining; original magnification, x200). H\&E, hematoxylin and eosin.
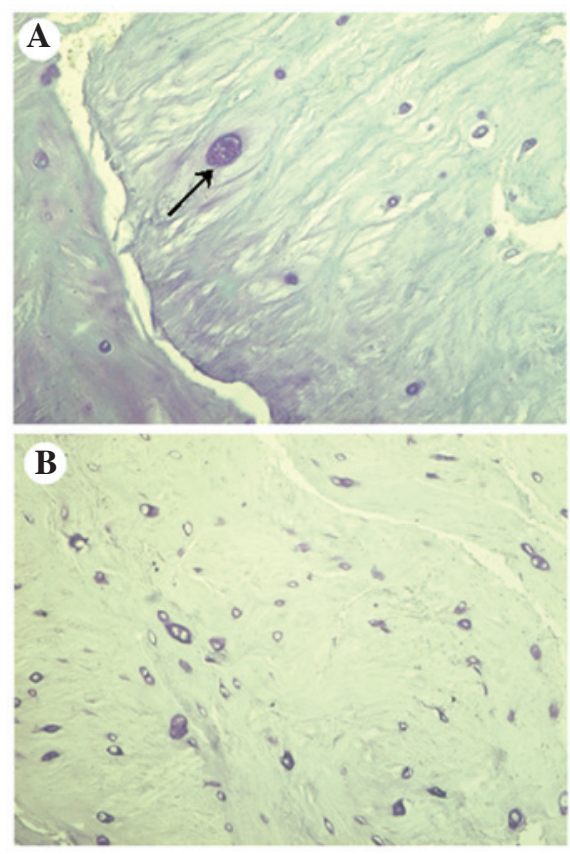

Figure 2. Classification of surgical specimens based on toluidine blue staining. (A) Grade 1, high toluidine blue metachromasia, clustering of chondrocytes and hypertrophic chondrocytes (highlighted by arrow) in herniated tissue (toluidine blue staining; original magnification, x200). (B) Grade 2, low toluidine blue metachromasia and absence of hypertrophic chondrocytes in herniated tissue (toluidine blue staining; original magnification, x200).

The sections were baked at $60^{\circ} \mathrm{C}$ for $1 \mathrm{~h}$, deparaffinized, rehydrated, immersed in $3 \% \mathrm{H}_{2} \mathrm{O}_{2}$ in phosphate-buffered saline (PBS) for $10 \mathrm{~min}$, heated in a sodium citrate bath in a microwave oven, washed in PBS and blocked in 10\% sheep 
Table I. Clinical characteristics of the 46 patients with lumbar disc herniation.

\begin{tabular}{|c|c|c|c|c|c|c|c|}
\hline Case no. & Gender & Age, years & Level (side) & $\begin{array}{c}\text { Duration of } \\
\text { sciatica, months }\end{array}$ & $\begin{array}{l}\text { SLR test, } \\
\text { degrees }\end{array}$ & $\begin{array}{l}\text { Sensory disturbance } \\
\text { of lower leg }\end{array}$ & $\begin{array}{c}\text { Muscle weakness } \\
\text { of lower leg }\end{array}$ \\
\hline 1 & $\mathrm{~F}$ & 22 & L5/S1 (R) & 6 & 40 & + & + \\
\hline 2 & M & 23 & $\mathrm{~L} 4 / 5$ (L) & 48 & 50 & - & - \\
\hline 3 & M & 28 & $\begin{array}{l}\mathrm{L} 4 / 5(\mathrm{R}) \\
\mathrm{L} 5 / \mathrm{S} 1(\mathrm{R})\end{array}$ & 24 & 40 & + & - \\
\hline 4 & $\mathrm{~F}$ & 55 & $\mathrm{~L} 4 / 5$ (L) & 2 & 45 & + & + \\
\hline 5 & $\mathrm{~F}$ & 53 & $\mathrm{~L} 4 / 5$ (L) & 1 & 30 & + & + \\
\hline 6 & M & 53 & $\begin{array}{l}\mathrm{L} 4 / 5(\mathrm{R}) \\
\mathrm{L} 5 / \mathrm{S} 1(\mathrm{R})\end{array}$ & 2 & 70 & + & - \\
\hline 7 & M & 46 & L5/S1 (R) & 0.2 & 50 & + & - \\
\hline 8 & M & 44 & $\mathrm{~L} 4 / 5(\mathrm{R})$ & 2 & 50 & - & + \\
\hline 9 & $\mathrm{~F}$ & 21 & L5/S1 (L) & 4 & 30 & + & - \\
\hline 10 & $\mathrm{~F}$ & 46 & L5/S1 (L) & 5 & 40 & - & - \\
\hline 11 & $\mathrm{~F}$ & 46 & $\mathrm{~L} 4 / 5(\mathrm{R})$ & 5 & 30 & + & + \\
\hline 12 & $\mathrm{~F}$ & 41 & L5/S1 (L) & 3 & 50 & + & + \\
\hline 13 & $\mathrm{~F}$ & 36 & $\begin{array}{l}\mathrm{L} 4 / 5(\mathrm{R}) \\
\mathrm{L} 5 / \mathrm{S} 1(\mathrm{R})\end{array}$ & 1 & 40 & + & + \\
\hline 14 & M & 52 & $\mathrm{~L} 4 / 5(\mathrm{R})$ & 1.2 & 50 & + & + \\
\hline 15 & M & 18 & $\mathrm{~L} 4 / 5(\mathrm{R})$ & 1 & 10 & + & + \\
\hline 16 & M & 42 & L5/S1 (R) & 10 & 50 & + & \\
\hline 17 & M & 56 & $\mathrm{~L} 4 / 5$ (L) & 1 & 45 & + & + \\
\hline 18 & M & 56 & $\mathrm{~L} 4 / 5$ (L) & 2 & 70 & + & + \\
\hline 19 & $\mathrm{~F}$ & 44 & $\begin{array}{l}\mathrm{L} 4 / 5(\mathrm{~L}) \\
\mathrm{L} 5 / \mathrm{S} 1(\mathrm{R})\end{array}$ & 1 & 30 & + & + \\
\hline 20 & $\mathrm{~F}$ & 52 & $\mathrm{~L} 3 / 4(\mathrm{R})$ & 0.3 & $\mathrm{FNST}^{+}$ & + & + \\
\hline 21 & $\mathrm{~F}$ & 47 & L5/S1 (R) & 4 & 50 & + & + \\
\hline 22 & M & 20 & $\mathrm{~L} 4 / 5(\mathrm{R})$ & 6 & 20 & + & - \\
\hline 23 & M & 39 & L4/5 (L) & 30 & 30 & + & - \\
\hline 24 & M & 54 & $\mathrm{~L} 4 / 5$ (R) & 0.3 & 40 & - & - \\
\hline 25 & M & 34 & $\mathrm{~L} 4 / 5(\mathrm{R})$ & 4 & 20 & + & + \\
\hline 26 & M & 54 & $\mathrm{~L} 4 / 5(\mathrm{R})$ & 2 & 30 & + & + \\
\hline 27 & $\mathrm{~F}$ & 44 & $\mathrm{~L} 4 / 5$ (L) & 2 & 30 & + & + \\
\hline 28 & M & 42 & $\mathrm{~L} 3 / 4(\mathrm{R})$ & 60 & $\mathrm{FNST}^{+}$ & + & + \\
\hline 29 & M & 58 & $\mathrm{~L} 4 / 5(\mathrm{R})$ & 2 & 40 & + & + \\
\hline 30 & M & 47 & L3/4 (L) & 48 & FNST $^{-}$ & + & + \\
\hline 31 & M & 52 & $\begin{array}{l}\mathrm{L} 4 / 5(\mathrm{~L}) \\
\mathrm{L} 5 / \mathrm{S} 1(\mathrm{R})\end{array}$ & 3 & 40 & + & + \\
\hline 32 & $\mathrm{~F}$ & 40 & L5/S1 (R) & 0.2 & 50 & + & + \\
\hline 33 & $\mathrm{~F}$ & 39 & $\begin{array}{l}\mathrm{L} 4 / 5(\mathrm{~L}) \\
\mathrm{L} 5 / \mathrm{S} 1(\mathrm{R})\end{array}$ & 12 & 30 & + & + \\
\hline 34 & $\mathrm{~F}$ & 56 & $\mathrm{~L} 4 / 5(\mathrm{~L})$ & 3 & 40 & + & + \\
\hline 35 & M & 76 & $\mathrm{~L} 4 / 5$ (R) & 6 & 30 & + & + \\
\hline 36 & $\mathrm{~F}$ & 67 & $\mathrm{~L} 4 / 5(\mathrm{R})$ & 2 & 70 & + & + \\
\hline 37 & $\mathrm{~F}$ & 68 & $\mathrm{~L} 4 / 5(\mathrm{R})$ & 8 & 20 & + & + \\
\hline 38 & $\mathrm{~F}$ & 63 & $\mathrm{~L} 4 / 5$ (L) & 2 & 0 & + & + \\
\hline 39 & $\mathrm{~F}$ & 40 & L4/5 (L) & 36 & 30 & + & + \\
\hline 40 & M & 48 & $\mathrm{~L} 4 / 5$ (L) & 36 & 70 & + & - \\
\hline 41 & M & 21 & L5/S1 (L) & 9 & 20 & + & - \\
\hline 42 & $\mathrm{~F}$ & 43 & $\mathrm{~L} 4 / 5$ (L) & 0.5 & 80 & + & - \\
\hline 43 & M & 52 & $\mathrm{~L} 4 / 5$ (L) & 0.7 & 30 & + & + \\
\hline 44 & $\mathrm{~F}$ & 52 & L5/S1 (R) & 0.3 & 30 & + & + \\
\hline 45 & $\mathrm{~F}$ & 39 & $\mathrm{~L} 4 / 5$ (L) & 12 & 30 & + & + \\
\hline 46 & M & 52 & L5/S1 (L) & 0.5 & 30 & + & + \\
\hline
\end{tabular}

F, female; M, male; R, right side; L, left side; FNST, femoral nerve stretch test; SLR, straight leg raise. 


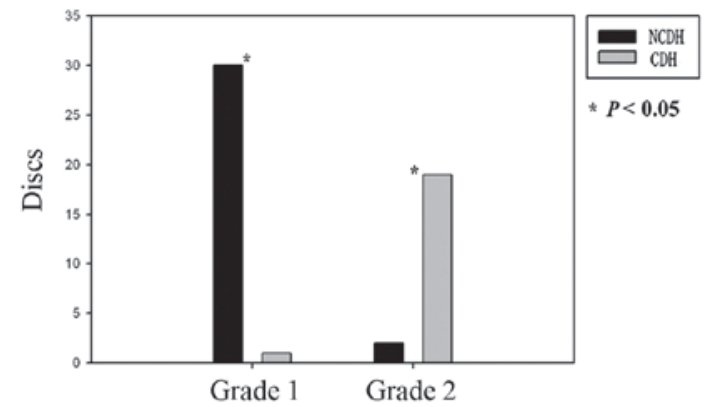

Type of pathological findings according to inflammatory cell infiltration and neovascularization

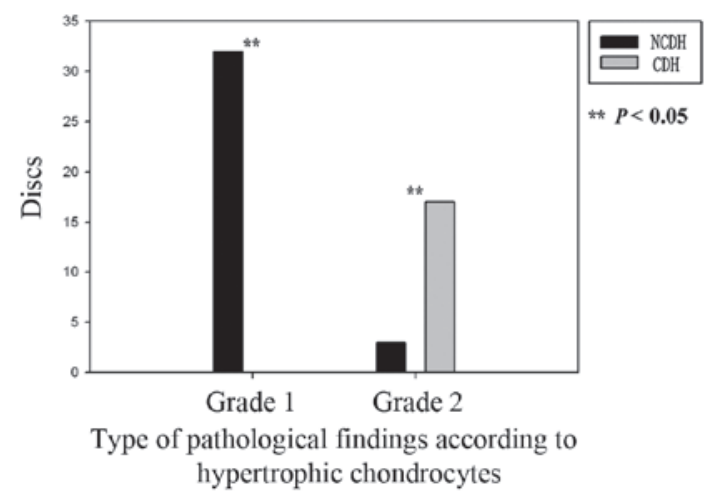

Figure 3. Comparison of surgical and pathological findings. $\mathrm{CDH}$, contained disc herniation; $\mathrm{NCDH}$, non-contained disc herniation.

serum for $15 \mathrm{~min}$ at room temperature. The sections were then incubated with primary rabbit polyclonal anti-human IL-17 antibodies (cat. no. sc-7927; Santa Cruz Biotechnology Inc., Santa Cruz, CA, USA), and diluted 1:50 in a blocking solution at $4^{\circ} \mathrm{C}$ in a humidified chamber overnight. Incubation with biotinylated secondary antibody (Tianjin Hao Yang Biological Manufacture Co. Ltd., Tianjin, China) was performed for $15 \mathrm{~min}$ at room temperature, and an avidin-biotin alkaline phosphatase complex reaction was performed for $15 \mathrm{~min}$, also at room temperature. Color was developed with diaminobenzidine, and the sections were counterstained with hematoxylin for $1 \mathrm{~min}$. Tris-buffered saline was used as a negative control instead of the primary antibodies, and the conditions were selected so that there was no signal in the negative control samples. Five slices of IVDs were used to determine the number of IL-17- immunoreactive cells per $0.015625 \mathrm{~mm}^{2}$ of histological section for each evaluation. The evaluation was blinded with respect to the grouping of the specimens.

Statistical analysis. The statistical significance of the differences in the neovascularization, granulation tissue and hypertrophic chondrocytes between the two groups was assessed using the $\chi^{2}$ test. The number of IL-17-immunoreactive cells in the herniated IVDs was compared by an independent-samples t-test. $\mathrm{P}<0.05$ indicated a statistically significant difference.

\section{Results}

Baseline characteristics. In Table I the clinical conditions of the patients have been introduced. Six patients suffered
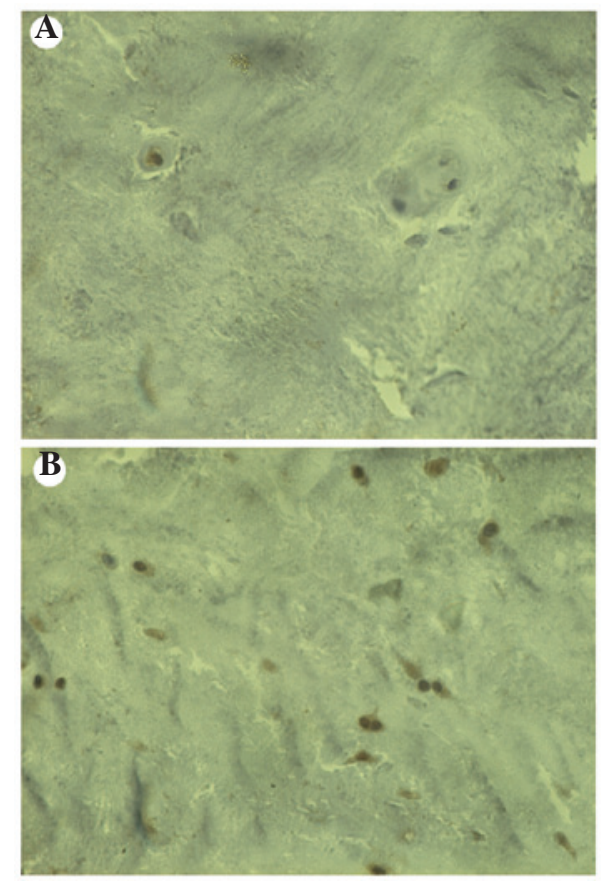

Figure 4. Herniated disc tissue analyzed by immunohistochemistry for IL-17. (A and B) IL-17-immunoreactive cells in (A) contained disc herniation and (B) non-contained disc herniation tissues (original magnification, $\mathrm{x} 400$ ). IL-17, interleukin 17.

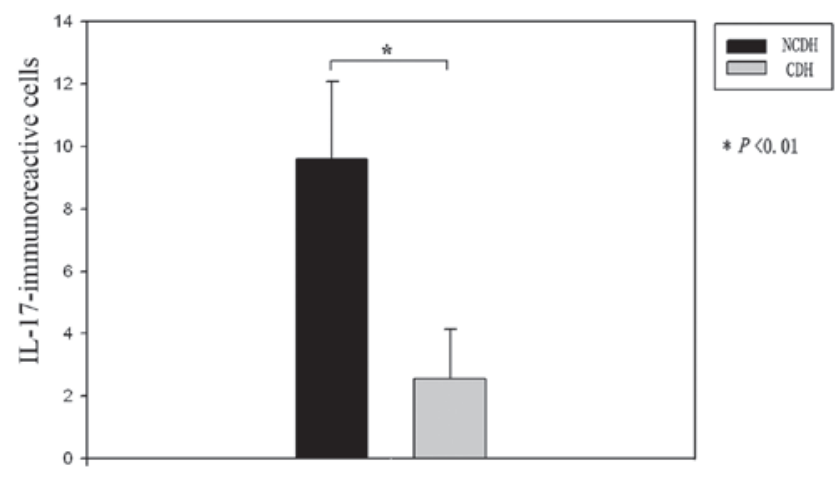

Figure 5. IL-17-immunoreactive cells. The number of IL-17-immunoreactive cells in tissues of the NCDH group was higher than that in tissues of the $\mathrm{CDH}$ group. $\mathrm{CDH}$, contained disc herniation; $\mathrm{NCDH}$, non-contained disc herniation.

from two segments of lumbar disc herniation so the age and male/female ratio could be compared in all patients.

Differences in the pathological results from the specimens collected from patients with $\mathrm{LDH}$. Thirty-one discs were classified as NCDH and 21 as CDH, based on the position of the IVD that was observed during the surgery (Table II). Neovascularization and granulation tissues were observed in 30 out of 31 (97\%) herniated tissues in the NCDH group. Hypertrophic chondrocytes were detected in the IVD specimens from the entire NCDH group (Fig. 3).

Pattern of distribution of IL-17-immunoreactive cells in the IVDs. IL-17 immunoreactivity was observed in the IVD specimens from both the $\mathrm{NCDH}$ and $\mathrm{CDH}$ groups. The 
Table II. Summary of surgical and pathological findings in the 46 patients with lumbar disc herniation.

\begin{tabular}{|c|c|c|c|c|}
\hline $\begin{array}{l}\text { Case } \\
\text { no. }\end{array}$ & $\begin{array}{l}\text { Level } \\
\text { (side) }\end{array}$ & $\begin{array}{c}\text { Type of } \\
\text { hernia }\end{array}$ & $\begin{array}{l}\text { Blood vessels } \\
\text { around hernia }\end{array}$ & $\begin{array}{l}\text { Hypertrophic } \\
\text { chondrocytes }\end{array}$ \\
\hline 1 & L5/S1 (R) & $\mathrm{NC}$ & 1 & I \\
\hline 2 & $\mathrm{~L} 4 / 5$ (L) & $\mathrm{C}$ & 2 & II \\
\hline \multirow[t]{2}{*}{3} & $\mathrm{~L} 4 / 5(\mathrm{R})$ & $\mathrm{C}$ & 2 & I \\
\hline & $\mathrm{L} 5 / \mathrm{S} 1(\mathrm{R})$ & $\mathrm{C}$ & 2 & II \\
\hline 4 & $\mathrm{~L} 4 / 5(\mathrm{~L})$ & $\mathrm{C}$ & 2 & II \\
\hline 5 & $\mathrm{~L} 4 / 5$ (L) & $\mathrm{NC}$ & 1 & I \\
\hline \multirow[t]{2}{*}{6} & $\mathrm{~L} 4 / 5(\mathrm{R})$ & $\mathrm{C}$ & 2 & II \\
\hline & L5/S1 (R) & $\mathrm{C}$ & 2 & II \\
\hline 7 & L5/S1 (R) & $\mathrm{NC}$ & 1 & II \\
\hline 8 & $\mathrm{~L} 4 / 5(\mathrm{R})$ & $\mathrm{C}$ & 1 & II \\
\hline 9 & L5/S1 (L) & $\mathrm{C}$ & 2 & II \\
\hline 10 & L5/S1 (L) & $\mathrm{C}$ & 2 & II \\
\hline 11 & $\mathrm{~L} 4 / 5(\mathrm{R})$ & $\mathrm{NC}$ & 1 & I \\
\hline 12 & L5/S1 (L) & $\mathrm{NC}$ & 1 & I \\
\hline \multirow[t]{2}{*}{13} & $\mathrm{~L} 4 / 5(\mathrm{R})$ & $\mathrm{C}$ & 2 & I \\
\hline & L5/S1 (R) & $\mathrm{C}$ & 2 & I \\
\hline 14 & $\mathrm{~L} 4 / 5(\mathrm{R})$ & $\mathrm{NC}$ & 1 & I \\
\hline 15 & $\mathrm{~L} 4 / 5$ (R) & $\mathrm{C}$ & 2 & II \\
\hline 16 & L5/S1 (R) & $\mathrm{C}$ & 2 & II \\
\hline 17 & $\mathrm{~L} 4 / 5$ (L) & $\mathrm{C}$ & 2 & II \\
\hline 18 & $\mathrm{~L} 4 / 5$ (L) & $\mathrm{NC}$ & 1 & II \\
\hline \multirow[t]{2}{*}{19} & L4/5 (L) & $\mathrm{C}$ & 2 & II \\
\hline & $\mathrm{L} 5 / \mathrm{S} 1(\mathrm{R})$ & $\mathrm{NC}$ & 2 & I \\
\hline 20 & $\mathrm{~L} 3 / 4(\mathrm{R})$ & $\mathrm{NC}$ & 1 & I \\
\hline 21 & L5/S1 (R) & $\mathrm{NC}$ & 1 & I \\
\hline 22 & $\mathrm{~L} 4 / 5(\mathrm{R})$ & $\mathrm{NC}$ & 1 & I \\
\hline 23 & $\mathrm{~L} 4 / 5$ (L) & $\mathrm{NC}$ & 2 & II \\
\hline 24 & $\mathrm{~L} 4 / 5$ (R) & $\mathrm{NC}$ & 1 & I \\
\hline 25 & $\mathrm{~L} 4 / 5$ (R) & $\mathrm{NC}$ & 1 & I \\
\hline 26 & $\mathrm{~L} 4 / 5(\mathrm{R})$ & $\mathrm{NC}$ & 1 & I \\
\hline 27 & $\mathrm{~L} 4 / 5$ (L) & $\mathrm{C}$ & 2 & II \\
\hline 28 & $\mathrm{~L} 3 / 4(\mathrm{R})$ & $\mathrm{NC}$ & 1 & I \\
\hline 29 & $\mathrm{~L} 4 / 5$ (R) & $\mathrm{NC}$ & 1 & I \\
\hline 30 & L3/4 (L) & $\mathrm{NC}$ & 1 & I \\
\hline \multirow[t]{2}{*}{31} & $\mathrm{~L} 4 / 5(\mathrm{~L})$ & $\mathrm{C}$ & 2 & II \\
\hline & $\mathrm{L} 5 / \mathrm{S} 1(\mathrm{R})$ & $\mathrm{C}$ & 2 & II \\
\hline 32 & $\mathrm{~L} 5 / \mathrm{S} 1(\mathrm{R})$ & $\mathrm{NC}$ & 1 & I \\
\hline \multirow[t]{2}{*}{33} & $\mathrm{~L} 4 / 5(\mathrm{~L})$ & $\mathrm{NC}$ & 1 & I \\
\hline & L5/S1 (L) & & 1 & I \\
\hline 34 & $\mathrm{~L} 4 / 5$ (L) & $\mathrm{NC}$ & 1 & I \\
\hline 35 & $\mathrm{~L} 4 / 5(\mathrm{R})$ & $\mathrm{NC}$ & 1 & I \\
\hline 36 & $\mathrm{~L} 4 / 5(\mathrm{R})$ & $\mathrm{NC}$ & 1 & I \\
\hline 37 & $\mathrm{~L} 4 / 5$ (R) & $\mathrm{C}$ & 2 & II \\
\hline 38 & $\mathrm{~L} 4 / 5$ (L) & $\mathrm{NC}$ & 1 & I \\
\hline 39 & $\mathrm{~L} 4 / 5$ (L) & $\mathrm{NC}$ & 1 & I \\
\hline 40 & $\mathrm{~L} 4 / 5$ (L) & $\mathrm{C}$ & 2 & II \\
\hline 41 & L5/S1 (L) & $\mathrm{NC}$ & 1 & I \\
\hline 42 & $\mathrm{~L} 4 / 5$ (L) & $\mathrm{NC}$ & 1 & I \\
\hline 43 & $\mathrm{~L} 4 / 5$ (L) & $\mathrm{NC}$ & 1 & I \\
\hline 44 & L5/S1 (R) & $\mathrm{NC}$ & 1 & I \\
\hline 45 & $\mathrm{~L} 4 / 5$ (L) & $\mathrm{NC}$ & 1 & I \\
\hline 46 & L5/S1 (L) & $\mathrm{NC}$ & 1 & I \\
\hline
\end{tabular}

$\mathrm{R}$, right side; $\mathrm{L}$, left side; $\mathrm{NC}$, non-contained disc herniation; $\mathrm{C}$, contained disc herniation. number of IL-17-immunoreactive cells in the IVD specimens from patients in the NCDH group was significantly greater than that in the IVD specimens from patients in the $\mathrm{CDH}$ group (Figs. 4 and 5).

\section{Discussion}

LDH is the most common cause of sciatica, a condition that severely limits the ability to perform daily activities. Although there is a high incidence of LDH in society, controversy still surrounds the pathogenesis and treatment of the disease. In 1962, Naylor proposed that chronic lower back pain could be due to an autoimmune mechanism (48). In the last few decades, numerous studies have proposed a possible immunological mechanism for nerve injury in LDH. By acting as a biochemical or immunological irritant, herniated disc material could contribute to a patient's clinical signs and symptoms (13-15).

Previous studies have provided evidence for the neovascularization and infiltration of macrophages and other inflammatory cells into herniated disc tissues $(12,49)$. In the current study, IVDs from patients with NCDH had significantly more neovascularization and granulation tissue than patients with $\mathrm{CDH}$. This is consistent with results from previous studies $(37,47)$, which showed that annulus fibrosus disruption could induce changes in the microenvironment surrounding herniated disc tissues. The present study evaluated the differences in neovascularization between the $\mathrm{CDH}$ and NCDH groups; however, no post-treatment follow-up evaluations were performed. A recent study has shown that severe histodegeneration in LDH is associated with enhanced neovascularization and a potentially spontaneous regression of the herniated tissue (50). The process of angiogenesis in the degenerated IVD affects the pre- and postoperative quality of life of the patients and may also serve as a predictive factor for postoperative results (51).

Through histological observations of intact rabbit IVDs, Kim et al (52) confirmed that chondrocytes in the NP originate from the cartilage endplate. Following the identification of chondrocytes in IVDs, an increasing number of studies have focused on the effects of chondrocyte apoptosis on physiological changes in IVDs $(52,53)$. The frequency of chondrocyte apoptosis in the sequestrated NP (SNP) and in the remaining NP (RNP) was the same (53). The pathways involved in chondrocyte apoptosis in the SNP and the RNP differed among individuals and included intrinsic and/or extrinsic pathways (53). In the current study, hypertrophic chondrocytes were more prevalent in specimens from the $\mathrm{NCDH}$ group than in specimens from the $\mathrm{CDH}$ group.

Immunohistochemical analysis showed that IL-17 was expressed in human herniated IVD tissues. IL-17 is a cytokine associated with inflammation and autoimmunity. The number of IL-17-immunoreactive cells found in the specimens from patients with $\mathrm{NCDH}$ was significantly higher than that found in the specimens from patients with $\mathrm{CDH}$.

The present study had a few limitations. Each group contained only a small number of cases, including patients of different ages; however, the intensity of pain or IL-17 expression in each patient was not compared. The results of this study suggest that the expression of IL-17 in herniated disc tissue may 
be a cause of lower back pain in LDH; however, further studies should be conducted in order to investigate the pathophysiological mechanisms of herniated disc tissue-induced pain.

In conclusion, the present results demonstrate that neovascularization, granulation tissue and hypertrophic chondrocytes are found in herniated disc tissues. IL-17 is expressed in human IVDs. Following its expression and secretion in inflamed human herniated disc tissues, IL-17 acts in an autoimmune manner to regulate inflammation and angiogenesis during the healing process. The present study demonstrates that IL-17 contributes to the pathogenesis of human IVD herniation by promoting autoimmune inflammation, chemotaxis and angiogenesis.

\section{Acknowledgements}

This study was supported by a grant from the Scientific Research Fund of Tianjin Municipal Administration of Traditional Chinese Medicine (grant no. 13123), National Natural Science Foundation of China (grant no. 81401792) and Project of Natural Science Foundation of Tianjin of China (grant no. 14JCQNJC11700).

\section{References}

1. McLain RF, Kapural L and Mekhail NA: Epidural steroids for back and leg pain: Mechanism of action and efficacy. Cleve Clin J Med 71: 961-970, 2004.

2. Geiss A, Larsson K, Rydevik B, Takahashi I and Olmarker K: Autoimmune properties of nucleus pulposus: An experimental study in pigs. Spine (Phila Pa 1976) 32: 168-173, 2007.

3. Hirsch C and Schajowicz F: Studies on structural changes in the lumbar annulus fibrosus. Acta Orthop Scand 22: 184-231, 1952.

4. Kanerva A, Kommonen B, Grönblad M, et al: Inflammatory cells in experimental intervertebral disc injury. Spine (Phila Pa 1976) 22: 2711-2715, 1997.

5. Olmarker K, Nordborg C, Larsson K and Rydevik B: Ultrastructural changes in spinal nerve roots induced by autologous nucleus pulposus. Spine (Phila Pa 1976) 21: 411-414, 1996.

6. Olmarker K, Iwabuchi M, Larsson K and Rydevik B: Walking analysis of rats subjected to experimental disc herniation. Eur Spine J 7: 394-399, 1998

7. Otani K, Arai I, Mao GP, et al: Nucleus pulposus-induced nerve root injury: Relationship between blood flow and motor nerve conduction velocity. Neurosurgery 45: 614-620, 1999.

8. Igarashi T, Kikuchi S, Shubayev V and Myers RR: 2000 Volvo Award winner in basic science studies: Exogenous tumor necrosis factor-alpha mimics nucleus pulposus-induced neuropathology. Molecular, histologic, and behavioral comparisons in rats. Spine (Phila Pa 1976) 25: 2975-2980, 2000.

9. Olmarker K, Størkson R and Berge OG: Pathogenesis of sciatic pain: A study of spontaneous behavior in rats exposed to experimental disc herniation. Spine (Phila Pa 1976) 27: 1312-1317, 2002

10. Kallakuri S, Takebayashi T, Ozaktay AC, et al: The effects of epidural application of allografted nucleus pulposus in rats on cytokine expression, limb withdrawal and nerve root discharge. Eur Spine J 14: 956-964, 2005.

11. Murata Y, Nannmark U, Rydevik B, et al: Nucleus pulposus-induced apoptosis in dorsal root ganglion following experimental disc herniation in rats. Spine (Phila Pa 1976) 31: 382-390, 2006

12. Shamji MF, Allen KD, So S, et al: Gait abnormalities and inflammatory cytokines in an autologous nucleus pulposus model of radiculopathy. Spine (Phila Pa 1976) 34: 648-654, 2009.

13. Saal JS, Franson RC, Dobrow R, et al: High levels of inflammatory phospholipase A2 activity in lumbar disc herniations. Spine (Phila Pa 1976) 15: 674-678, 1990.

14. Goupille P, Jayson MI, Valat JP and Freemont AJ: The role of inflammation in disk herniation-associated radiculopathy. Semin Arthritis Rheum 28: 60-71, 1998.
15. Tolonen J, Grönblad M, Vanharanta H, et al: Growth factor expression in degenerated intervertebral disc tissue. An immunohistochemical analysis of transforming growth factor beta, fibroblast growth factor and platelet-derived growth factor. Eur Spine J 15: 588-596, 2006.

16. Nagano T, Yonenobu K, Miyamoto S, et al: Distribution of the basic fibroblast growth factor and its receptor gene expression in normal and degenerated rat intervertebral discs. Spine (Phila Pa 1976) 20: 1972-1978, 1995.

17. Tolonen J, Grönblad M, Virri J, et al: Basic fibroblast growth factor immunoreactivity in blood vessels and cells of disc herniations. Spine (Phila Pa 1976) 20: 271-276, 1995.

18. Kang JD, Stefanovic-Racic M, McIntyre LA, et al: Toward a biochemical understanding of human intervertebral disc degeneration and herniation. Contributions of nitric oxide, interleukins, prostaglandin E2, and matrix metalloproteinases. Spine (Phila Pa 1976) 22: 1065-1073, 1997.

19. Kang JD, Georgescu HI, McIntyre-Larkin L, et al: Herniated lumbar intervertebral discs spontaneously produce matrix metalloproteinases, nitric oxide, interleukin- 6 , and prostaglandin E2. Spine (Phila Pa 1976) 21: 271-277, 1996.

20. Brisby H, Byröd G, Olmarker K, et al: Nitric oxide as a mediator of nucleus pulposus-induced effects on spinal nerve roots. J Orthop Res 18: 815-820, 2000.

21. Richardson SM, Doyle P, Minogue BM, et al: Increased expression of matrix metalloproteinase-10, nerve growth factor and substance $\mathrm{P}$ in the painful degenerate intervertebral disc. Arthritis Res Ther 11: R126, 2009.

22. Takahashi H, Suguro T, Okazima Y, et al: Inflammatory cytokines in the herniated disc of the lumbar spine. Spine (Phila Pa 1976) 21: 218-224, 1996.

23. Ozaktay AC, Cavanaugh JM, Asik I, et al: Dorsal root sensitivity to interleukin-1 beta, interleukin- 6 and tumor necrosis factor in rats. Eur Spine J 11: 467-475, 2002.

24. Hoyland JA, Le Maitre C and Freemont AJ: Investigation of the role of IL-1 and TNF in matrix degradation in the intervertebral disc. Rheumatology (Oxford) 47: 809-814, 2008.

25. Geiss A, Larsson K, Junevik K, et al: Autologous nucleus pulposus primes T cells to develop into interleukin-4-producing effector cells: An experimental study on the autoimmune properties of nucleus pulposus. J Orthop Res 27: 97-103, 2009.

26. Rand N, Reichert F, Floman Y and Rotshenker S: Murine nucleus pulposus-derived cells secrete interleukins-1-beta, -6, and -10 and granulocyte-macrophage colony-stimulating factor in cell culture. Spine (Phila Pa 1976) 22: 2598-2602, 1997.

27. Burke JG, Watson RW, McCormack D, et al: Intervertebral discs which cause low back pain secrete high levels of proinflammatory mediators. J Bone Joint Surg Br 84: 196-201, 2002.

28. Huang K-Y, Lin R-M, Chen W-Y, et al: IL-20 may contribute to the pathogenesis of human intervertebral disc herniation. Spine (Phila Pa 1976) 33: 2034-2040, 2008.

29. O'Donnell JL and O'Donnell AL: Prostaglandin E2 content in herniated lumbar disc disease. Spine (Phila Pa 1976) 21: 1653-1656, 1996

30. Olmarker K and Larsson K: Tumor necrosis factor alpha and nucleus-pulposus-induced nerve root injury. Spine (Phila $\mathrm{Pa}$ 1976) 23: 2538-2544, 1998.

31. Yoshida T, Park JS, Yokosuka K, et al: Effect of a nonprotein bioactive agent on the reduction of cyclooxygenase-2 and tumor necrosis factor-alpha in human intervertebral disc cells in vitro. J Neurosurg Spine 9: 411-418, 2008.

32. Iwabuchi S, Ito M, Chikanishi $\mathrm{T}$, et al: Role of the tumor necrosis factor-alpha, cyclooxygenase-2, prostaglandin E2, and effect of low-intensity pulsed ultrasound in an in vitro herniated disc resorption model. J Orthop Res 26: 1274-1278, 2008.

33. Ohtori S, Inoue G, Koshi T, et al: Substance P-saporin down-regulates substance $\mathrm{P}$ receptor immunoreactive sensory dorsal root ganglion neurons innervating the lumbar intervertebral discs in rats. Spine (Phila Pa 1976) 31: 2987-2991, 2006.

34. Miyamoto H, Saura R, Harada T, et al: The role of cyclooxygenase- 2 and inflammatory cytokines in pain induction of herniated lumbar intervertebral disc. Kobe J Med Sci 46: 13-28, 2000.

35. Miyamoto H, Saura R, Doita M, et al: The role of cyclooxygenase-2 in lumbar disc herniation. Spine (Phila Pa 1976) 27: 2477-2483, 2002.

36. Yoshida M, Nakamura T, Kikuchi T, et al: Expression of monocyte chemoattractant protein-1 in primary cultures of rabbit intervertebral disc cells. J Orthop Res 20: 1298-1304, 2002. 
37. Haro H, Kato T, Komori H, et al: Vascular endothelial growth factor (VEGF)-induced angiogenesis in herniated disc resorption. J Orthop Res 20: 409-415, 2002.

38. Caruso R, Pallone F and Monteleone G: Emerging role of IL-23/IL-17 axis in $\mathrm{H}$ pylori-associated pathology. World J Gastroenterol 13: 5547-5551, 2007.

39. Fujino S, Andoh A, Bamba S, et al: Increased expression of interleukin 17 in inflammatory bowel disease. Gut 52: 65-70, 2003.

40. Loffredo S, Ayala F, Marone G, et al: Immunopathogenesis of psoriasis and pharmacological perspectives. J Rheumatol Suppl 83: 9-11, 2009.

41. Hwang SY and Kim HY: Expression of IL-17 homologs and their receptors in the synovial cells of rheumatoid arthritis patients. Mol Cells 19: 180-184, 2005.

42. Hou W, Kang HS and Kim BS: Th17 cells enhance viral persistence and inhibit $\mathrm{T}$ cell cytotoxicity in a model of chronic virus infection. J Exp Med 206: 313-328, 2009.

43. Kokubu T, Haudenschild DR, Moseley TA, et al: Immunolocalization of IL-17A, IL-17B, and their receptors in chondrocytes during fracture healing. J Histochem Cytochem 56: 89-95, 2008

44. Shamji MF, Allen KD, So S, et al: Gait abnormalities and inflammatory cytokines in an autologous nucleus pulposus model of radiculopathy. Spine (Phila Pa 1976) 34: 648-654, 2009.

45. Shamji MF, Setton LA, Jarvis W, et al: Proinflammatory cytokine expression profile in degenerated and herniated human intervertebral disc tissues. Arthritis Rheum 62: 1974-1982, 2010 .
46. Cheng L, Fan W, Liu B, et al: Th17 lymphocyte levels are higher in patients with ruptured than non-ruptured lumbar discs, and are correlated with pain intensity. Injury 44: 1805-1810, 2013.

47. Kobayashi S, Meir A, Kokubo Y, et al: Ultrastructural analysis on lumbar disc herniation using surgical specimens: Role of neovascularization and macrophages in hernias. Spine (Phila Pa 1976) 34: 655-662, 2009.

48. Naylor A: The biophysical and biochemical aspects of intervertebral disc herniation and degeneration. Ann R Coll Surg Engl 31: 91-114, 1962.

49. Doita M, Kanatani T, Ozaki T, et al: Influence of macrophage infiltration of herniated disc tissue on the production of matrix metalloproteinases leading to disc resorption. Spine (Phila Pa 1976) 26: 1522-1527, 2001

50. Rätsep T, Minajeva A and Asser T: Relationship between neovascularization and degenerative changes in herniated lumbar intervertebral discs. Eur Spine J 22: 2474-2480, 2013.

51. David G, Ciurea AV, Iencean SM and Mohan A: Angiogenesis in the degeneration of the lumbar intervertebral disc. J Med Life 3: 154-161, 2010.

52. Kim KW, Lim TH, Kim JG, et al: The origin of chondrocytes in the nucleus pulposus and histologic findings associated with the transition of a notochordal nucleus pulposus to a fibrocartilaginous nucleus pulposus in intact rabbit intervertebral discs. Spine (Phila Pa 1976) 28: 982-990, 2003.

53. Ha KY, Kim BG, Kim KW, et al: Apoptosis in the sequestrated nucleus pulposus compared to the remaining nucleus pulposus in the same patient. Spine (Phila Pa 1976) 36: 683-689, 2011. 